\title{
Research on Environmental, Economic, and Social Sustainability in Dairy Farming: A Systematic Mapping of Current Literature
}

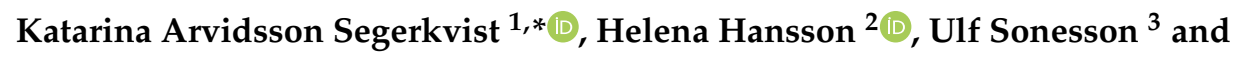 \\ Stefan Gunnarsson ${ }^{1}$ (D) \\ 1 Department of Animal Environment and Health, Swedish University of Agricultural Sciences (SLU), \\ P.O. Box 234, S-53223 Skara, Sweden; Stefan.gunnarsson@slu.se \\ 2 Department of Economics, Swedish University of Agricultural Sciences (SLU), P.O. Box 7013, \\ S-75007 Uppsala, Sweden; helena.hansson@slu.se \\ 3 RISE Research Institutes of Sweden, P.O. Box 5401, S-40229 Göteborg, Sweden; ulf.sonesson@ri.se \\ * Correspondence: Katarina.segerkvist@slu.se; Tel.: +46-511-671-44
}

Received: 3 June 2020; Accepted: 1 July 2020; Published: 8 July 2020

\begin{abstract}
Dairy cows are able to convert fibrous materials, such as grass, roughage, and by-products from the food industry, into milk and meat, which justifies their role in food production. However, modern dairy farming is associated with major sustainability challenges, including greenhouse gas emissions. In order to develop sustainable future production, it is important to implement existing knowledge and fill knowledge gaps. The aim of this study was to systematically map the scientific literature on environmental, economic, and social sustainability at farm level in dairy farming. Literature published between January 2000 and March 2020 and with the geographical focus on Europe, North America, and Australia-New Zealand was included. In total, the literature search resulted in 169 hits, but after removing duplicates and papers outside the study scope only 35 papers remained. Of these, only 11 dealt with the three dimensions of sustainability, and several of these only mentioned one or two of the dimensions or set them in relation to that/those actually studied. Overall, the selected literature did not clearly explain how aspects of sustainability are interlinked, so possible negative or positive interactions between different aspects of sustainability dimensions remain unidentified.
\end{abstract}

Keywords: dairy cow; animal welfare; ecology; life cycle assessment; sustainable production

\section{Introduction}

In 2018, there were over 290 million dairy cows worldwide, producing almost 700 million tonnes of milk [1]. India has the greatest number of dairy cows in the world, over 50 million $(17.6 \%$ of the global dairy cow population), but the United States of America is the largest producer of milk, producing over 98 million tonnes per year (14\% of world milk production [1]). Comparing global regions, Europe accounts for $32 \%$ of world production, the Americas for $27 \%$, Asia for $31 \%$, Africa for $5 \%$, and Oceania for $4 \%$ [1]. Cow's milk is a valuable source of nutrients, providing humans with energy, protein, essential minerals, and vitamins. In addition, dairy farming provides the main income for many farmers around the world. As such, dairy farming contributes to several of the 17 global Sustainable Development Goals (SDG) set by the United Nations, including SDG1: Zero hunger, SDG3: Good health and wellbeing, and SDG8: Decent work and economic growth [2,3]. However, dairy farming may also jeopardize other SDGs, including SDG13: Climate action and SDG15: Life on land. Global average whole-milk consumption in 2017 was $88 \mathrm{~kg}$ per person, with very significant differences between countries/regions. Per capita consumption in Western Europe was almost $270 \mathrm{~kg}$ 
of milk per person in that year, compared with $35 \mathrm{~kg}$ in Africa [1]. With more than $70 \%$ of global agricultural land already being used to produce feed for livestock [4], there are limited possibilities to increase the area of arable land. Hence, it is increasingly important to use non-human edible products as animal feed and to increasingly utilize areas for animal feed that cannot be used for production of foods that are directly edible to humans. Cattle are able to convert fibrous materials, such as roughage and other grass from permanent grasslands and by-products from the food industry into milk and meat, which justifies their role in food production [5].

Nevertheless, modern dairy farming is associated with major sustainability challenges. One of the most pressing is emissions of greenhouse gases (GHGs) to the atmosphere. Methane $\left(\mathrm{CH}_{4}\right)$ production from gastroenteric fermentation in dairy cows is not only an energy loss for the animal, but also a contributor to GHG emissions [6]. Around 6\% of gross energy intake in dairy cows is lost as $\mathrm{CH}_{4}$, of which approximately $95 \%$ is lost via the mouth and 2-3\% through feces [7]. Enteric $\mathrm{CH}_{4}$ is responsible for around $50 \%$ of all GHG emissions along the production chain of milk in Western countries, and an even higher percentage in developing countries with low-yielding cows [8]. Other important GHG contributions are emissions of carbon dioxide $\left(\mathrm{CO}_{2}\right)$ and nitrous oxide $\left(\mathrm{N}_{2} \mathrm{O}\right)[9]$. In addition, dairy farming can have major adverse impacts on watercourses due to nitrogen and phosphorus emissions from manure spreading and from over-grazed fields. Production of feed involves environmental impact and resource use, with the severity depending on the crop production system and local conditions $[10,11]$. From a societal perspective, there is also increasing concern about the welfare of farm animals [12,13], including dairy cows. At the same time, economic margins in dairy production are generally slim.

Over the past decade, growing recognition of the environmental challenges caused by agricultural production, continuous economic competition resulting in decreasing farm income, and animal welfare concerns have resulted in increasing interest in sustainable animal food production [14]. A sustainable production system is characterized by inclusion of the different dimensions of sustainability, i.e., environmental, economic, and social. In 1987, the Brundtland Commission [15] defined sustainable development as "development that meets the needs of the present without compromising the ability of future generations to meet their own needs". Sustainable agriculture has been defined as the management and use of agricultural ecosystems in a way that maintains, both today and in the future, biological diversity, regeneration capacity, vitality, and productivity [16]. It also aims to achieve significant ecological, economic, and social functions at local, national, and global level, and does not harm ecosystems [16]. Sustainable livestock production has been defined in one study as "production that is ecologically sound, taking into account the environment and biodiversity, ethically and economically sustainable" [17], but no universal definition exists. Furthermore, in animal food production, sustainability includes many ecological issues, since if the environment is damaged it cannot sustain production that relies on natural systems [16]. However, for the production system to function, overall economic viability is essential. Agriculture is generally performed by private businesses, and revenues need to exceed costs, at least over the long term, in order for these firms, and thereby production, to survive. Neglecting the economic sustainability of agriculture may reduce interest among stakeholders in taking necessary actions to improve environmental performance and social conditions. Farmers' quality of life or sense of wellbeing is influenced by, among other factors, social and technical relations within production $[18,19]$, and thus the social sustainability dimension of farming considers farmers' quality of life. Social sustainability can also be related to acceptance by society of agricultural practices. Societal concerns about farm animal welfare [12,13] is one important aspect of this, as it links directly to human thoughts and feelings about livestock production. Agriculture is often considered by policy makers to be the main driver of rural economic development and growth, so it is also expected to contribute to the social sustainability of rural communities. Sustainability of agriculture is therefore truly an outcome of the three dimensions of sustainable development. 
Valentin and Spangenberg [20] highlighted a fourth dimension of sustainability, namely institutional sustainability. While social sustainability refers to human capital and capabilities, institutional sustainability can be defined as the human interactions and the rules under which they are governed [20]. However, since this fourth dimension of sustainability is rarely mentioned in other literature this paper focus on environmental, economic, and social sustainability.

To date, much research has been devoted to sustainability and different dimensions of sustainability in dairy farming. However, the process of developing more sustainable future dairy production systems would benefit from an overview of the current state of knowledge in this area of research, including how the concept of sustainability is perceived. This would serve as a useful basis for highlighting important knowledge gaps and for prioritizing future actions and research initiatives. To our knowledge, there have been no previous attempts to map current knowledge on sustainability in dairy farming in a systematic way. The aim of this study was thus to systematically map the scientific literature on farm-level sustainability in dairy production. In order to limit the scope, the analysis was restricted to studies conducted in Europe, North America, Australia, and New Zealand, which enabled comparisons of production systems located in similar economic contexts.

\section{Materials and Methods}

The work presented in this paper is part of a larger project, other findings from which have been published previously [21,22].

\subsection{Definition of Fundamental Concepts within Sustainability}

Sustainability is a holistic concept, but it needs to be split into different dimensions that can be analyzed empirically, which in turn provide a basis for further scientific analyses on a higher level, e.g., to investigate possible negative or positive interactions between different aspects of sustainability. When evaluating the sustainability of a specific production system, it is important to include all these different dimensions (environmental, economic, and social). In this study, the three dimensions of sustainability were defined as follows:

\subsubsection{Environmental Sustainability}

The environmental dimension of sustainability is a natural science-based aspect that, basically, includes the total impact human activities may have on the ecosystems. Life cycle analysis (LCA) is the most commonly used approach for quantification of the environmental impact. It concerns the flows of resources (energy, land, water etc.) to the production system and emissions from the system and quantifies potential impacts. All environmental impacts caused by emissions, at all levels, should be included as well as the perspective of resource availability both locally, regionally, and globally. The focus of environmental sustainability assessments should be the effect of total production and not the organizational boundaries, i.e., all flows to and from production systems needs to be accounted for, regardless of economic ownership [23]. In addition to LCA, there are other methods assessing the environmental impact. In essence, most are similar in terms of the basic principles, but may use different approaches for describing the impacts. As an example, in the ecological footprint approach, all emissions and resources used are converted into "hypothetical area used", generating a common unit for the environmental impact of single products, which makes communication and comparison of differences between systems easier [24].

\subsubsection{Economic Sustainability}

From a theoretical perspective, economic sustainability can be considered in two ways. One focuses on the sustainable use of natural resources within a defined economic system, meaning that economic sustainability is achieved when the economic activity is not undertaken at the cost of natural resources. This economic concept of external effects is useful in understanding and fully capturing costs associated with production. The other way of considering economic sustainability focuses on growth of the 
economic system. Basically, this implies that in order to achieve economic sustainability, there must be a return on capital invested in the firm. When it comes to evaluation of natural and economic capital, there are two different approaches: weak and strong sustainability $[25,26]$. In weak sustainability, the sum of those two types of capital is combined, whereas in strong sustainability natural and economic capital are evaluated separately [26]. There is no clear consensus on how best to measure economic sustainability [27]. However, the sustainability accounting standards produced by the Global Reporting Initiatives [28] provide some guidance on which aspects to consider. In terms of economic indicators, these standards include aspects such as costs, revenues, profit, and investments.

\subsubsection{Social Sustainability}

Social sustainability is the least well defined and most often overlooked dimension of sustainability [29]. Social sustainability can be defined as the development of social structures and processes that meet the needs of the present in a community at the same time as laying a foundation for the community to continue to develop in a sustainable way in the future. In this study, the social dimension of sustainability included aspects such as community development, community resilience, livelihood, social equity, health equity, and labor rights. Aspects not directly associated with human societies, such as animal health and welfare, were also included in this dimension.

\subsection{Systematic Mapping Approach}

For the present analysis, we applied a systematic mapping approach, also known as evidence gap mapping. Systematic mapping is a transparent, robust, and repeatable method used to identify, collect, and assort relevant literature concerning a particular research topic [30]. It provides a structured overview of the research area [31], but without aiming to synthesize or further process the study results [32]. Instead, the method serves to identify and gather the published knowledge within a given research area and to indicate knowledge gaps where future research is needed. In contrast, a systematic review aims to answer a specific research question [32] through gathering relevant literature, further synthesizing the results using an appropriate methodology, e.g., meta-analysis [31,32], and specifically identifying knowledge gaps. However, the latter was beyond the scope of the current work. In this study, the systematic mapping approach was complemented with an approach whereby we extracted data from the set of papers reviewed to describe how sustainability dimensions considered in each paper were identified. Using a template, extracted keywords were defined and categorized to get an overview of aspects studied.

\subsection{Literature Search}

A comprehensive search of available online literature databases was conducted to obtain an impartial selection of published literature. To identify relevant papers, the online databases Scopus, Web of Science Core Collection, and CABI (https://clarivate.com/webofsciencegroup/solutions/ webofscience-cab-abstracts/): Cab Abstracts were used. The searches were limited to papers published between January 1, 2000 and March 20, 2020.

To find relevant papers in relation to dairy farming, the following search terms were used: "('dairy cow $^{* \prime}$ Or 'dairy herd ${ }^{* \prime}$ Or 'dairy cattle' Or (milk* W/2 herd*))". These were then combined with search terms for environmental, economic, and social sustainability (Table 1), which were defined through an iterative process by all co-authors, in collaboration with a university librarian. The co-authors have expertise in different areas and could thus identify search terms and indicators usually used in relation to the three sustainability dimensions. In Scopus, the search was made within the search field "Title, Abstract, Keywords". In Web of Science Core Collection and CABI: Cab Abstracts, the searches were made within "Topic", which includes title, abstract, and keywords. 
Table 1. Library search terms used to locate papers dealing with on-farm environmental, economic, and social sustainability in dairy farming.

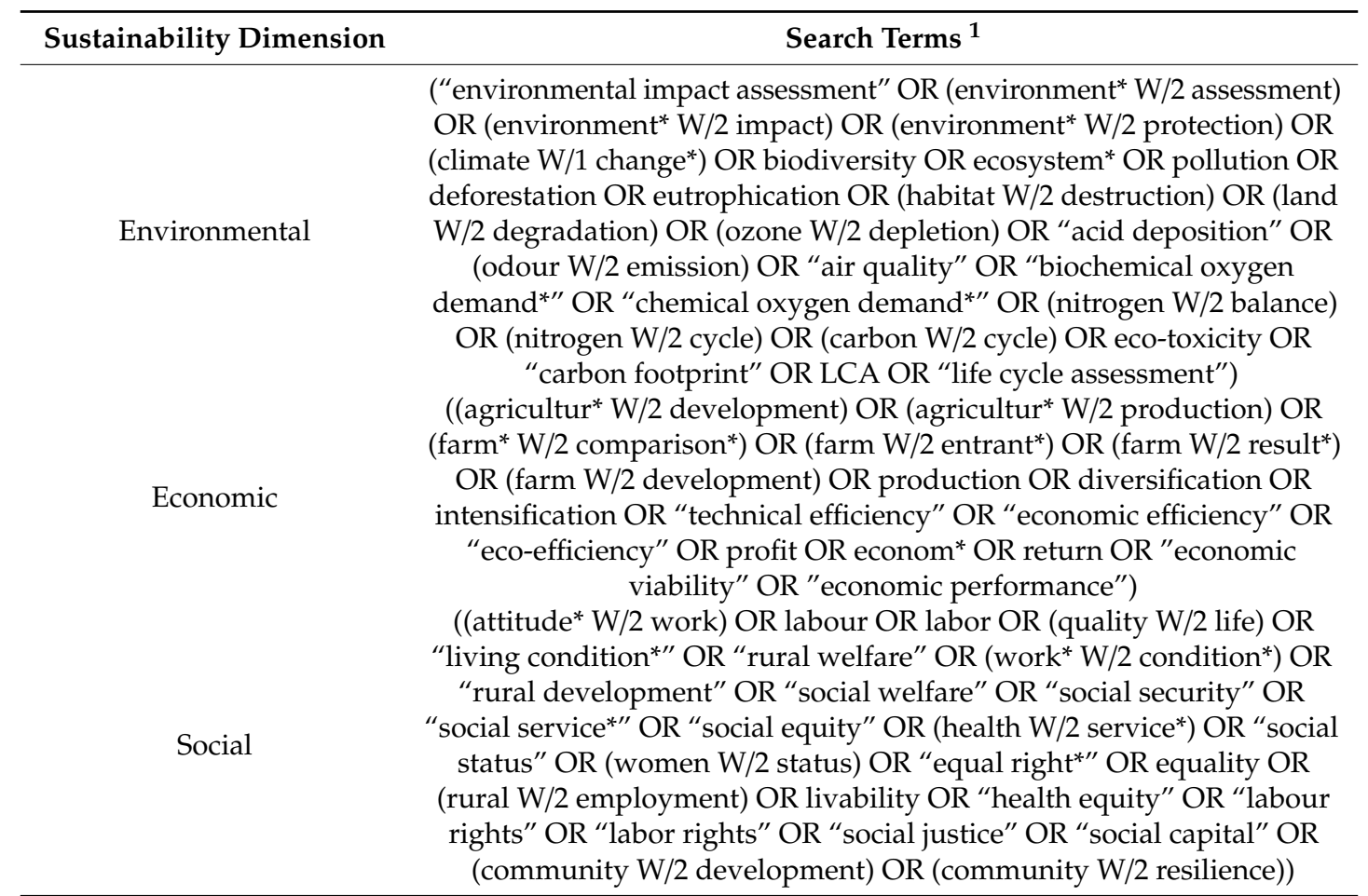

\footnotetext{
${ }^{1}$ The Boolean operator $\mathrm{W}$ was used for the search in Scopus, while the Boolean operator NEAR was used for the
} searches in Web of Science Core Collection and CABI: CAB Abstracts.

The results of the searches were imported into the reference management software EndNote $\mathrm{X} 8{ }^{\mathrm{TM}}$. For each search in the three databases, a separate library was made, and the number of references found was recorded. After the searches were complete, the libraries were merged into one single library. Any duplicates were removed using the automatic function in the EndNote $\mathrm{X} 8^{\mathrm{TM}}$ software. The retrieved library was then manually searched for papers relevant to sustainability in dairy farming. Only full-length, trial-based papers were included, i.e., literature reviews, book chapters, conference papers, and organization reports were excluded. This to ensure that only original, peer reviewed papers were included. Further, the full-length papers had to be written in English to be included. In addition to ensuring that the articles addressed sustainability (single dimensions or a combination of dimensions), a geographical limitation was also set, whereby only studies conducted in Europe, North America, and Australia-New Zealand were included, to enable a focus on studies conducted on production systems in similar economic contexts. Exclusion due to publication type, language, or geographical origin was performed manually and was not set up in the searches.

Using a template, data were extracted from the abstracts of the hits identified, in order to describe aspects of the three sustainability dimensions dealt with in each paper. In the template, keywords used in each study to describe sustainability were defined and categorized. The full text of selected papers that listed aspects of the dimensions of sustainability in the abstract was analyzed in order to assess the actual scientific content on the three dimensions, i.e., to determine whether all dimensions were empirically studied.

\section{Results}

The literature search resulted in a total of 169 hits, of which $101(60 \%)$ originated from CABI: Cab Abstracts, 36 (21\%) originated from Web of Science Core Collection, and 32 (19\%) originated from Scopus. After removing duplicates and articles that did not match the scope of the study, i.e., non-peer-reviewed reports, book chapters, conference abstracts, review papers, and papers not written 
in English, there remained a total of 35 papers, which were categorized in terms of sustainability dimensions and analyzed in the systematic mapping process (Table 2, Appendix A). A majority of these (28/35 papers) originated from Europe, while five originated from North America and two from Australia-New Zealand.

Table 2. Categorization of the set of 35 papers included in systematic mapping in terms of their coverage of the environmental, economic, and social dimensions of sustainability in dairy farming

\begin{tabular}{|c|c|c|c|c|}
\hline \multirow{2}{*}{ No. } & \multirow{2}{*}{ Author/s ${ }^{1}$} & \multicolumn{3}{|c|}{ Sustainability Dimensions } \\
\hline & & Environmental & Economic & Sociala \\
\hline 1. & Alvåsen et al., 2018 & & & $x$ \\
\hline 2. & Câmara et al., 2001 & $x$ & & \\
\hline 3. & Chen and Holden, 2017 & & & $x$ \\
\hline 4. & Einarsson et al., 2018 & $x$ & & \\
\hline 5. & Fairweather et al., 2009 & & & \\
\hline 6. & Filson et al., 2003 & $x$ & $x$ & $x$ \\
\hline 7. & Flaten, 2002 & & $x$ & $x$ \\
\hline 8. & Groot et al., 2012 & $x$ & $x$ & \\
\hline 9. & Hessle et al., 2017 & $x$ & $x$ & \\
\hline 10. & Kiley-Worthington, 2014 & $x$ & $x$ & $x$ \\
\hline 11. & Klootwijk et al., 2016 & $x$ & $x$ & $x$ \\
\hline 12. & Konovalchuk et al., 2008 & $x$ & & $x$ \\
\hline 13. & Lehtonen, 2015 & $x$ & $x$ & $x$ \\
\hline 14. & Lengers et al., 2014 & $x$ & $x$ & \\
\hline 15. & Marton et al., 2016 & $x$ & $x$ & $x$ \\
\hline 16. & Meng, 2015 & $x$ & $x$ & $x$ \\
\hline 17. & Meul et al., 2012 & $x$ & $x$ & $x$ \\
\hline 18. & Mosnier et al., 2017 & $x$ & $x$ & $x$ \\
\hline 19. & Nordborg et al., 2017 & $x$ & & \\
\hline 20. & Noyes et al., 2016 & $x$ & & \\
\hline 21. & Oudshoorn et al., 2012 & $x$ & $x$ & $x$ \\
\hline 22. & Paudel et al., 2004 & $x$ & & $x$ \\
\hline 23. & Rebhann et al., 2016 & $x$ & $x$ & $x$ \\
\hline 24. & Röös et al., 2016a & $x$ & $x$ & $x$ \\
\hline 25. & Röös et al., 2016b & $x$ & & $x$ \\
\hline 26. & Sandu et al., 2014 & & $x$ & \\
\hline 27. & Sasu-Boakye et al., 2014 & $x$ & & \\
\hline 28 & van Calker et al., 2004 & $x$ & $x$ & \\
\hline 29. & van Calker et al., 2005 & $x$ & $x$ & $x$ \\
\hline 30. & van Middelaar et al., 2013 & $x$ & $x$ & \\
\hline 31. & van Middelaar et al., 2014a & $x$ & $x$ & \\
\hline 32. & van Middelaar et al., 2014b & $x$ & $x$ & \\
\hline 33. & van Middelaar et al., 2015 & $x$ & $x$ & \\
\hline 34. & van Passel et al., 2007 & $x$ & $x$ & \\
\hline \multirow[t]{2}{*}{35.} & Vigne et al., 2013 & $\mathrm{x}$ & & \\
\hline & Total & 30 & 23 & 18 \\
\hline
\end{tabular}

The papers were assessed regarding environmental, economic, and social sustainability and whether one, two, or all three dimensions were covered within each article. However, during the mapping process it was found that aspects of the different sustainability dimensions were only mentioned briefly in some papers, e.g., in the abstract or introduction, without actually being part of the study. In other papers, one or two dimensions were actually measured and analyzed, and the third was discussed in relation to those studied. Only around one-third (31\%) of the 35 papers in the final set actually included the three dimensions in the same study. 
During the reading process, data describing aspects of the sustainability dimensions that were studied in each paper were extracted and categorized (Figure 1).

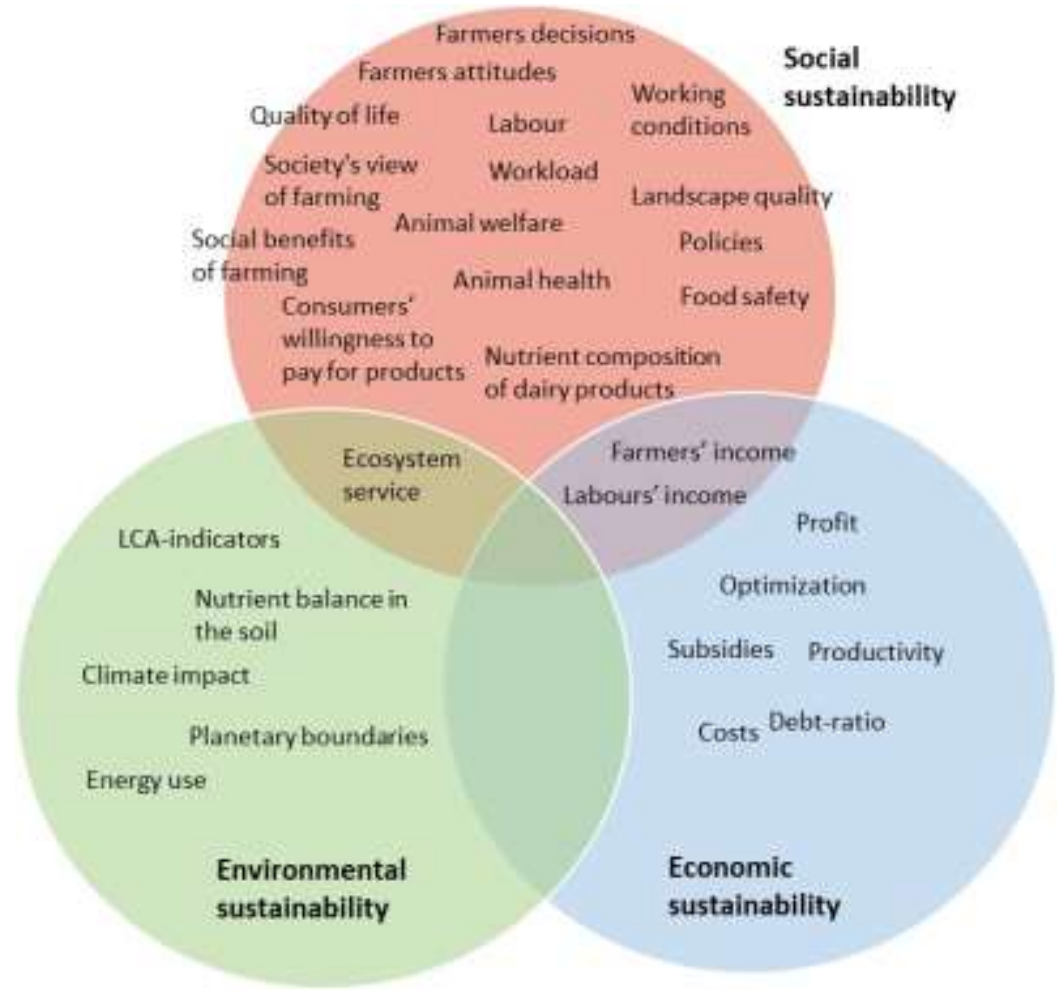

Figure 1. Categorized keywords based on data extracted from papers covering, or mentioning, different aspects of sustainability in dairy farming.

Regarding environmental sustainability, the main focus in the 30 papers covering this dimension was on climate impact (GHG emissions) and nutrient balance, including manure handling and fertilization regimes. Factors studied in relation to GHG emissions were most often different feeding strategies, but genetic traits were included in one study. Energy use and renewable energy sources were also studied, but to a lesser extent. One paper reported studies on how to integrate farming with wildlife conservation.

In the 23 papers covering economic sustainability, it was often measured as labor income in different production systems, using different feeding strategies and in relation to policy changes. Production costs for grass and cereals were linked to animal productivity in some studies. In addition, some studies calculated the cost per tonnes of $\mathrm{CO}_{2}$ emissions under different scenarios. In one study, the opportunity cost of land if oat drink were to be produced instead of cow's milk was calculated.

A wide variety of social sustainability aspects were included in the 18 papers that covered this dimension. Aspects raised by several studies were labor (both requirement and efficiency), working conditions (work load, working hours), and farmers' income. Other aspects raised were food safety, nutritional composition of the milk, the attitude of society to farming, and consumer wiliness to pay for products with added benefits, e.g., milk from grazing cows. In addition, policy making and how new policies affect farm structure, management, and labor income were studied. Farmers' attitudes and the factors on which they base different decisions were mentioned. One paper dealt with antimicrobial resistance.

Six of the papers in the set included animal welfare as part of the sustainability concept. Aspects covered by these papers were grazing regimes, animal longevity, use of growth hormones, and societal concerns about animal welfare. 
Almost half (49\%) of the 35 papers included were based on modelling and/or scenario analyses (Figure 2). The majority ( $83 \%$ ) of these studies considered the present day as the time perspective, $9 \%$ were future looking, $6 \%$ compared the past with the present, and $3 \%$ considered the situation before and after a change.
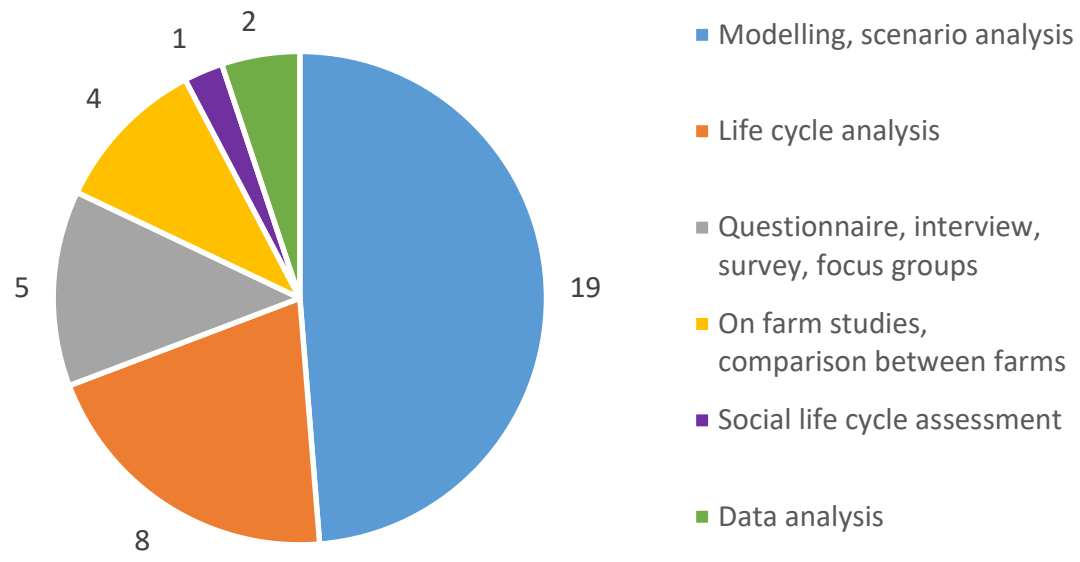

Figure 2. Type of study conducted in the 35 papers included in the systematic mapping. Some individual papers comprised several types of studies, and therefore appear in several categories.

\section{Discussion and Conclusions}

Using a systematic mapping approach provided a good overview of the currently available scientific literature on sustainability in dairy production, including the environmental, economic, and social dimensions of sustainable development, and of the current state of knowledge within this research area. This provided a basis for discussing knowledge gaps and priority areas for future research. We found that only 11 of the 35 papers in the final set analyzed the three sustainability dimensions within dairy production. Although sustainability has been an important topic of discussion since the Brundtland report [15] was published more than 30 years ago and although dairy farming is an important part of livestock production in many countries, there have been surprisingly few studies covering the three dimensions of sustainability simultaneously. However, papers covering one or two sustainability dimensions were more common. Dairy farming today is associated with major sustainability challenges, mostly in relation to the environment due to the GHG emissions. This was reflected in the number of papers dealing with environmental sustainability, as 30 of the 35 papers analyzed studied aspects relating to environmental impact. Economic sustainability (23/35 papers) was studied to a larger extent than social sustainability (18/35 papers). Social sustainability was also more commonly covered or mentioned in association with one or both of the other two dimensions rather than on its own.

In the systematic mapping approach, the search terms are carefully defined in an iterative process to enable maximum coverage of the published scientific literature within the area of the study. However, even though we included search terms for the three dimensions of sustainability in our searches, we found that only a small proportion of the search hits actually dealt with environmental, economic, and social sustainability in the same study. There may of course be additional studies that have covered these issues, but which did not appear among the hits as they may not have contained the exact words used in our search strings. Creating a search string that is specific enough to locate relevant papers and that is also fully inclusive is a challenge, and hence no literature search is complete. Thus, there may have been relevant papers that were not located in our searches. However, since the search strings used can be considered comprehensive, the searches most likely identified the majority of studies dealing with sustainability within dairy production.

Considering the definitions of sustainability in dairy farming, a major challenge was the very wide range of aspects used in the different papers in relation to the sustainability dimensions. For example, 
the term "environmental sustainability" was used in different papers to describe studies covering everything from full-scale LCA to anaerobic reactor performance when digesting dairy manure. Regarding social sustainability, there is no uniform definition of this dimension, which was reflected in the even wider variety of aspects found in the papers analyzed. The variety of aspects studied in relation to the different sustainability dimensions makes it complicated to compare between studies, both due to the many different aspects and to the different approaches used in the included papers. One priority area for future research should be to develop a nomenclature to define and categorize various aspects of the sustainability dimensions. This would help to make better comparisons between studies and to draw further conclusions.

As can be seen in Table 1, animal welfare was not initially included among our search terms as an aspect of social sustainability, but it was added during the mapping process. Animal welfare is a multifaceted concept that can be argued as a part of both environmental, economic, and social sustainability. For example, improved animal health (which leads to reduced use of antibiotics) is not only important for the animal itself, but also for environmental sustainability (increased resource efficiency, reduced drug residues, and resistant bacteria in soil), economic sustainability (reduced costs and increased productivity), and social sustainability (public health, product quality, and food safety) $[33,34]$. It should perhaps be added as an additional dimension of sustainability. However, the public is increasingly aware of animal welfare $[12,13]$ and is thus closely linked to the societal view of animal production. Further, as animals are living individuals, which are part of the social system on farms as well as the society as whole, the concept can be considered to relate to social sustainability. Hence, in this study we included animal welfare in the social dimension of sustainability. It is also important to bear in mind that other aspects of sustainable development may be connected to each other in similar ways. During the reading process for this study, it became apparent that the current literature does not describe or consider these interrelations or discuss possible negative or positive interactions between different aspects of sustainability dimensions. This is an important area for future research.

Institutional, or governance, sustainability has been identified as a fourth dimension of sustainability [20]. Dairy farming, including both crop production and animal husbandry, is regulated both at national and international level. Hence, it is valuable to also include the institutional or governance dimension when studying sustainability in relation to dairy farming. None of the papers included in the systematic mapping have mentioned this dimension, let alone included it in the study. However, a number of the studies have included aspects such as policies within the framework of social sustainability, although policies clearly should be included in institutional sustainability.

Almost half of the papers analyzed were based on modelling or scenario analysis. This is an efficient approach to investigate how different management regimes, both feeding regimes and fertilization regimes, will affect, e.g., the economic outcome or the environmental impact. However, it is important that the data used as input to the calculations are valid and up-to-date, so that representative estimates can be obtained. This is important both from an environmental, economic, and social perspective. In agriculture, conditions vary between countries, and between regions within countries, in terms of climate (e.g., temperature, precipitation), soil type, etc. Further, different countries have different laws and regulations that affect the dairy production in general and perhaps the economy in particular. This makes it even more important to ensure that the data used is valid for the type of production and for the conditions where the results will be applied. Otherwise, the actions based on the outcomes may not achieve their full potential in efforts to achieve sustainable dairy production.

When working on the systematic mapping, we identified a number of aspects that can provide a basis for identifying research gaps and prioritizing future actions. The aim of the study was not to create and extensive list of actions that need to be taken, which would require a systematic review of the literature, but there are three issues worth highlighting.

First, it is evident that the number of published studies that actually cover both environmental, economic, and social sustainability simultaneously on farm level is low. We found that 11 of the 
35 papers included in the systematic mapping included the three dimensions of sustainability, but in several of these cases one or two of the dimensions were only mentioned in passing or in relation to that/those actually studied. In addition, almost half the papers included in final set were based on modelling or scenario analyses. This indicates a need for more holistic assessments of sustainability in dairy farming and empirical applications of such methods.

Second, during the mapping process it emerged that a very wide range of aspects are used in the literature to describe different aspects of sustainability at farm level. Further, none of the studies had included the institutional dimension of sustainability, but some of the studies included aspects related to this dimension within the social dimension instead. This makes it difficult to compare different studies and to combine results to get a broader picture. The contribution of previous research is highly valuable, but future studies should take a more comprehensive approach, i.e., include the different dimensions of sustainability within the same study and consider how different aspects of sustainability in dairy farming are best measured, based on a conceptual understanding of sustainability. A common, standardized vocabulary would allow comparison of studies to a greater extent. Further, a standardized way of measuring different aspects of sustainability could lead to a wider area of application for data obtained.

Third, it is not yet well understood how different aspects of the sustainability dimensions are interlinked, and possible positive or negative interactions between them remain unidentified. Knowledge of these interactions would be valuable when seeking to determine how individual aspects of sustainability can be promoted and how the whole system at farm level can be improved.

Author Contributions: Conceptualization, S.G., H.H., U.S., K.A.S. and Investigation, K.A.S.; Data Curation, K.A.S.; Formal Analysis, K.A.S.; Writing-Original Draft Preparation, K.A.S.; Review and Editing, H.H., U.S., and S.G.; Funding Acquisition, S.G. All authors have read and agreed to the published version of the manuscript.

Funding: The Swedish Research Council, Formas, grant number 2017-02017, funded this research.

Acknowledgments: We thank Mattias Lennartsson, librarian at the Swedish University of Agricultural Sciences, for valuable help during the process of developing the search strings.

Conflicts of Interest: The authors declare no conflict of interest. The funders had no role in the design of the study; in the collection, analyses, or interpretation of data; in the writing of the manuscript, or in the decision to publish the results.

\section{Appendix A}

Papers included in the systematic mapping:

1. Alvåsen, K.; Dohoo, I.; Roth, A.; Emanuelson, U. Farm characteristics and management routines related to cow longevity: A survey among Swedish dairy farmers. Acta Veterinaria Scandinavica 2018, 60, 38, doi:10.1186/s13028-018-0390-8.

2. Câmara, E.E.G.; Duarte, E.A.; Ferreira, L. Overall assessment of environmental impacts of animal production in Portugal. Anais do Instituto Superior de Agronomia 2001, 48, 9-40. Available online: http://hdl.handle.net/10400.5/16099 (accessed on 2 April 2020)

3. Chen, W.; Holden, N.M. Social life cycle assessment of average Irish dairy farm. The International Journal of Life Cycle Assessment 2017, 22, 1459-1472, doi:10.1007/s11367-016-1250-2.

4. Einarsson, R.; Cederberg, C.; Kallus, J. Nitrogen flows on organic and conventional dairy farms: A comparison of three indicators. Nutrient Cycling in Agroecosystems 2018, 110, 25-38, doi:10.1007/s10705-017-9861-y.

5. Fairweather, J.R.; Hunt, L.M.; Rosin, C.J.; Campbell, H.R. Are Conventional Farmers Conventional? Analysis of the Environmental Orientations of Conventional New Zealand Farmers. Rural Sociology 2009, 74, 430-454, doi:10.1526/003601109789037222.

6. Filson, G.C.; Pfeiffer, W.C.; Paine, C.; Taylor, J.R. The Relationship Between Grand River Dairy Farmers' Quality of Life and Economic, Social and Environmental Aspects of Their Farming Systems. J. Sustain. Agriculture 2003, 22, 61-77, doi:10.1300/J064v22n01_05. 
7. Flaten, O. Alternative rates of structural change in Norwegian dairy farming: impacts on costs of production and rural employment. Journal of Rural Studies 2002, 18, 429-441, doi: 10.1016/S0743-0167(02)00031-1.

8. Groot, J.C.J.; Oomen, G.J.M.; Rossing, W.A.H. Multi-objective optimization and design of farming systems. Agricultural Systems 2012, 110, 63-77, doi: 10.1016/j.agsy.2012.03.012.

9. Hessle, A.; Bertilsson, J.; Stenberg, B.; Kumm, K.-I.; Sonesson, U. Combining environmentally and economically sustainable dairy and beef production in Sweden. Agricultural Systems 2017, 156, 105-114, doi:10.1016/j.agsy.2017.06.004.

10. Kiley-Worthington, M. Ecological Agriculture. Integrating Low Input, High Productive Farming with Wildlife Conservation. Results from the Experimental Farm La Combe, Drome France. Open Journal of Ecology 2014, 4, 744-763, doi:10.4236/oje.2014.412064.

11. Klootwijk, C.W.; Van Middelaar, C.E.; Berentsen, P.B.M.; de Boer, I.J.M. Dutch dairy farms after milk quota abolition: Economic and environmental consequences of a new manure policy. Journal of dairy science 2016, 99, 8384-8396, doi: 10.3168/jds.2015-10781.

12. Konovalchuk, V.; Hanson, G.D.; Luloff, A.E. Layered community support for sustainable dairy farming. Journal of Extension 2008, 46, 6FEA3. Available online: https://www.joe.org/joe/ 2008december/a3.php (accessed on 2 April 2020)

13. Lehtonen, H.S. Evaluating adaptation and the production development of Finnish agriculture in climate and global change. Agricultural and Food Science 2015, 24, 219-234, doi:10.23986/afsci.51080.

14. Lengers, B.; Britz, W.; Holm-Müller, K. What Drives Marginal Abatement Costs of Greenhouse Gases on Dairy Farms? A Meta-modelling Approach. Journal of Agricultural Economics 2014, 65, 579-599, doi:10.1111/1477-9552.12057.

15. Marton, S.M.R.R.; Zimmermann, A.; Kreuzer, M.; Gaillard, G. Environmental and socioeconomic benefits of a division of labour between lowland and mountain farms in milk production systems. Agricultural Systems 2016, 149, 1-10, doi:https://doi.org/10.1016/j.agsy.2016.07.015.

16. Meng, S. Is the agricultural industry spared from the influence of the Australian carbon tax? Agricultural Economics 2015, 46, 125-137, doi:10.1111/agec.12145.

17. Meul, M.; Van Passel, S.; Fremaut, D.; Haesaert, G. Higher sustainability performance of intensive grazing versus zero-grazing dairy systems. Agronomy for Sustainable Development 2012, 32, 629-638, doi:10.1007/s13593-011-0074-5.

18. Mosnier, C.; Duclos, A.; Agabriel, J.; Gac, A. Orfee: A bio-economic model to simulate integrated and intensive management of mixed crop-livestock farms and their greenhouse gas emissions. Agricultural Systems 2017, 157, 202-215, doi:10.1016/j.agsy.2017.07.005.

19. Nordborg, M.; Sasu-Boakye, Y.; Cederberg, C.; Berndes, G. Challenges in developing regionalized characterization factors in land use impact assessment: impacts on ecosystem services in case studies of animal protein production in Sweden. The International Journal of Life Cycle Assessment 2017, 22, 328-345, doi:10.1007/s11367-016-1158-x.

20. Noyes, N.R.; Yang, X.; Linke, L.M.; Magnuson, R.J.; Cook, S.R.; Zaheer, R.; Yang, H.; Woerner, D.R.; Geornaras, I.; McArt, J.A., et al. Characterization of the resistome in manure, soil and wastewater from dairy and beef production systems. Scientific Reports 2016, 6, 24645, doi:10.1038/srep24645.

21. Oudshoorn, F.W.; Kristensen, T.; van der Zijpp, A.J.; Boer, I.J.M.d. Sustainability evaluation of automatic and conventional milking systems on organic dairy farms in Denmark. NJAS Wageningen Journal of Life Sciences 2012, 59, 25-33, doi:10.1016/j.njas.2011.05.003.

22. Paudel, K.P.; Gauthier, W.M.; Westra, J.V.; Hall, L.M. Dairy programs to reduce manure-related environmental problems: The case of the Louisiana milkshed. Journal of Environmental Systems 2004, 31, 367-383, doi: 10.2190/ES.31.4.f

23. Rebhann, M.; Karatay, Y.N.; Filler, G.; Prochnow, A. Profitability of Management Systems on German Fenlands. Sustainability 2016, 8, 1103, doi.org/10.3390/su8111103 
24. Röös, E.; Patel, M.; Spångberg, J. Producing oat drink or cow's milk on a Swedish farm Environmental impacts considering the service of grazing, the opportunity cost of land and the demand for beef and protein. Agricultural Systems 2016, 142, 23-32, doi:10.1016/j.agsy.2015.11.002.

25. Röös, E.; Patel, M.; Spångberg, J.; Carlsson, G.; Rydhmer, L. Limiting livestock production to pasture and by-products in a search for sustainable diets. Food Policy 2016, 58, 1-13, doi:10.1016/j.foodpol.2015.10.008.

26. Sandu, M.; Tobă, G.F.; Paraschivescu, M.T. Bioeconomical research on biodiversity of animal food resources in Romania. Romanian Biotechnological Letters 2014, 19, 9597-9604. Available online: https://e-repository.org/rbl/vol.19/iss.4/16.pdf (accessed 5 April 2020)

27. Sasu-Boakye, Y.; Cederberg, C.; Wirsenius, S. Localising livestock protein feed production and the impact on land use and greenhouse gas emissions. Animal 2014, 8, 1339-1348, doi:10.1017/S1751731114001293.

28. van Calker, K.J.; Berentsen, P.B.M.; de Boer, I.M.J.; Giesen, G.W.J.; Huirne, R.B.M. An LP-model to analyse economic and ecological sustainability on Dutch dairy farms: model presentation and application for experimental farm "de Marke". Agricultural Systems 2004, 82, 139-160, doi:https://doi.org/10.1016/j.agsy.2004.02.001.

29. van Calker, K.J.; Berentsen, P.B.M.; Giesen, G.W.J.; Huirne, R.B.M. Identifying and ranking attributes that determine sustainability in Dutch dairy farming. Agriculture and Human Values 2005, 22, 53-63, doi:10.1007/s10460-004-7230-3.

30. van Middelaar, C.E.; Berentsen, P.B.M.; Dijkstra, J.; De Boer, I.J.M. Evaluation of a feeding strategy to reduce greenhouse gas emissions from dairy farming: The level of analysis matters. Agricultural Systems 2013, 121, 9-22, doi:10.1016/j.agsy.2013.05.009

31. van Middelaar, C.E.; Berentsen, P.B.M.; Dijkstra, J.; van Arendonk, J.A.M.; de Boer, I.J.M. Methods to determine the relative value of genetic traits in dairy cows to reduce greenhouse gas emissions along the chain. Journal of dairy science 2014, 97, 5191-5205, doi:10.3168/jds.2013-7413.

32. van Middelaar, C.E.; Dijkstra, J.; Berentsen, P.B.; De Boer, I.J. Cost-effectiveness of feeding strategies to reduce greenhouse gas emissions from dairy farming. Journal of dairy science 2014, 97, 2427-2439, doi:10.3168/jds.2013-7648.

33. van Middelaar, C.E.; Berentsen, P.B.M.; Dijkstra, J.; Van Arendonk, J.A.M.; De Boer, I.J.M. Effect of feed-related farm characteristics on relative values of genetic traits in dairy cows to reduce greenhouse gas emissions along the chain. Journal of dairy science 2015, 98, 4889-4903, doi:10.3168/jds.2014-8310.

34. van Passel, S.; Nevens, F.; Mathijs, E.; Van Huylenbroeck, G. Measuring farm sustainability and explaining differences in sustainable efficiency. Ecological Economics 2007, 62, 149-161, doi:10.1016/j.ecolecon.2006.06.008.

35. Vigne, M.; Vayssières, J.; Lecomte, P.; Peyraud, J.-L. Pluri-energy analysis of livestock systems - A comparison of dairy systems in different territories. Journal of Environmental Management 2013, 126, 44-54, doi:10.1016/j.jenvman.2013.04.003.

\section{References}

1. FAO. FAOSTAT database. Available online: http://www.fao.org/faostat/en/\#home (accessed on 2 April 2020).

2. UN. Sustainable Development Goals. Available online: https://www.un.org/development/desa/en/news/ sustainable/sustainable-development-goals.html (accessed on 22 February 2019).

3. UN. Global Sustainable Development Report; 2015. Available online: https://sustainabledevelopment. un.org/content/documents/1758GSDR\%202015\%20Advance\%20Unedited\%20Version.pdf (accessed on 14 April 2020).

4. FAO. The State of Food and Agriculture. Livestock in the Balance; Food and Agriculture Organization of the United Nations: Rome, Italy, 2009. Available online: http://www.fao.org/3/a-i0680e.pdf (accessed on 14 April 2020). 
5. Patel, M.; Sonesson, U.; Hessle, A. Upgrading plant amino acids through cattle to improve the nutritional value for humans: Effects of different production systems. Animal 2017, 11, 519-528. [CrossRef] [PubMed]

6. Ellis, J.L.; Dijkstra, J.; Kebreab, E.; Bannink, A.; Odongo, N.E.; McBride, B.W.; France, J. Aspects of rumen microbiology central to mechanistic modelling of methane production in cattle. J. Agric. Sci. 2008, 146, 213-233. [CrossRef]

7. Murray, R.M.; Bryant, A.M.; Leng, R.A. Rates of production of methane in the rumen and large intestine of sheep. Br. J. Nutr. 1976, 36, 1-14. [CrossRef] [PubMed]

8. FAO and GDP. Climate Change and the Global Dairy Cattle Sector-The Role of the Dairy Sector in a Low-Carbon Future; Food and Agriculture Organization of the United Nations and Global Dairy Platform Inc.: Rome, Rome, Italy, 2018. Available online: http://www.fao.org/3/CA2929EN/ca2929en.pdf (accessed on 14 April 2020).

9. Hörtenhuber, S.; Lindenthal, T.; Amon, B.; Markut, T.; Kirner, L.; Zollitsch, W. Greenhouse gas emissions from selected Austrian dairy production systems-Model calculations considering the effects of land use change. Renew. Agric. Food Syst. 2010, 25, 316-329. [CrossRef]

10. Nguyen, T.T.H.; Doreau, M.; Corson, M.S.; Eugène, M.; Delaby, L.; Chesneau, G.; Gallard, Y.; van der Werf, H.M.G. Effect of dairy production system, breed and co-product handling methods on environmental impacts at farm level. J. Environ. Manag. 2013, 120, 127-137. [CrossRef]

11. Gourley, C.J.P.; Aarons, S.R.; Powell, J.M. Nitrogen use efficiency and manure management practices in contrasting dairy production systems. Agric. Ecosyst. Environ. 2012, 147, 73-81. [CrossRef]

12. European Commission. Attitudes of Europeans towards Animal Welfare; Directorate-General for Communication: Brussels, Belgium, 2015. Available online: http://data.europa.eu/88u/dataset/S2096_84_4_442_ENG (accessed on 14 April 2020).

13. Ingenbleek, P.T.M.; Immink, V.M. Consumer decision-making for animal-friendly products: Synthesis and implications. Anim. Welf. 2011, 20,11-19. Available online: https://www.ingentaconnect.com/content/ufaw/ aw/2011/00000020/00000001/art00003 (accessed on 2 April 2020).

14. van Calker, K.J.; Berentsen, P.B.M.; Giesen, G.W.J.; Huirne, R.B.M. Identifying and ranking attributes that determine sustainability in Dutch dairy farming. Agric. Hum. Values 2005, 22, 53-63. [CrossRef]

15. Brundtland, G.H. Our Common Future-Call for Action. Environ. Conserv. 1987, 14, 291-294. [CrossRef]

16. Tilman, D.; Cassman, K.G.; Matson, P.A.; Naylor, R.; Polasky, S. Agricultural sustainability and intensive production practices. Nature 2002, 418, 671-677. [CrossRef]

17. Torp-Donner, H.; Juga, J. Sustainability-A challenge to animal production and breeding. Agric. Food Sci. 1997, 6, 229-239. [CrossRef]

18. Filson, G.C.; Pfeiffer, W.C.; Paine, C.; Taylor, J.R. The Relationship Between Grand River Dairy Farmers' Quality of Life and Economic, Social and Environmental Aspects of Their Farming Systems. J. Sustain. Agric. 2003, 22, 61-77. [CrossRef]

19. Filson, G.C.; McCoy, M. Farmers' Quality of Life: Sorting Out the Differences by Class. Rural Sociol. 1993, 13, 15-37. Available online: https://eric.ed.gov/?id=EJ467596 (accessed on 5 April 2020).

20. Valentin, A.; Spangenberg, J.H. A guide to community sustainability indicators. Environ. Impact Assess. Rev. 2000, 20, 381-392. [CrossRef]

21. Gunnarsson, S.; Arvidsson Segerkvist, K.; Wallgren, T.; Hansson, H.; Sonesson, U. A Systematic Mapping of Research on Sustainability Dimensions at Farm-level in Pig Production. Sustainability 2020, 12, 4352. [CrossRef]

22. Gunnarsson, S.; Arvidsson Segerkvist, K.; Göransson, L.; Hansson, H.; Sonesson, U. Systematic Mapping of Research on Farm-Level Sustainability in Egg and Chicken Meat Production. Sustainability 2020, 12, 3033. [CrossRef]

23. Notarnicola, B.; Sala, S.; Anton, A.; McLaren, S.J.; Saouter, E.; Sonesson, U. The role of life cycle assessment in supporting sustainable agri-food systems: A review of the challenges. J. Clean. Prod. 2017, 140, 399-409. [CrossRef]

24. Collins, A.; Fairchild, R. Sustainable Food Consumption at a Sub-national Level: An Ecological Footprint, Nutritional and Economic Analysis. J. Environ. Policy Plan. 2007, 9, 5-30. [CrossRef]

25. Ayres, R.U.; van den Bergh, J.C.J.M.; Gowdy, J.M. Strong versus weak sustainability: Economics, natural sciences and 'consilience'. Environ. Ethics 2001, 23, 155-168. [CrossRef]

26. van den Bergh, J.C.J.M. Externality or sustainability economics? Ecol. Econ. 2010, 69, 2047-2052. [CrossRef] 
27. Montiel, I.; Delgado-Ceballos, J. Defining and Measuring Corporate Sustainability: Are We There Yet? Organ. Environ. 2014, 27, 113-139. [CrossRef]

28. Alliances, G.S. Global Reporting Initiative. Available online: https:/www.globalreporting.org/standards/ (accessed on 5 April 2020).

29. Vallance, S.; Perkins, H.C.; Dixon, J.E. What is social sustainability? A clarification of concepts. Geoforum 2011, 42, 342-348. [CrossRef]

30. Snilstveit, B.; Vojtkova, M.; Bhavsar, A.; Stevenson, J.; Gaarder, M. Evidence \& Gap Maps: A tool for promoting evidence informed policy and strategic research agendas. J. Clin. Epidemiol. 2016, 79, 120-129. [CrossRef] [PubMed]

31. Petersen, K.; Vakkalanka, S.; Kuzniarz, L. Guidelines for conducting systematic mapping studies in software engineering: An update. Inf. Softw. Technol. 2015, 64, 1-18. [CrossRef]

32. James, K.L.; Randall, N.P.; Haddaway, N.R. A methodology for systematic mapping in environmental sciences. Environ. Evid. 2016, 5, 7. [CrossRef]

33. Mie, A.; Andersen, H.R.; Gunnarsson, S.; Kahl, J.; Kesse-Guyot, E.; Rembialkowska, E.; Quaglio, G.; Grandjean, P. Human health implications of organic food and organic agriculture: A comprehensive review. Environ. Health 2017, 16, 22. [CrossRef]

34. Amador, P.; Duarte, I.M.; da Costa, R.P.R.; Fernandes, R.; Prudencio, C. Characterization of Antibiotic Resistance in Enterobacteriaceae From Agricultural Manure and Soil in Portugal. Soil Sci 2017, 182, 292-301. [CrossRef]

(C) 2020 by the authors. Licensee MDPI, Basel, Switzerland. This article is an open access article distributed under the terms and conditions of the Creative Commons Attribution (CC BY) license (http://creativecommons.org/licenses/by/4.0/). 